\title{
THE PRESENT AND FUTURE STATE OF THE CLIMATE IN POLAND AND BULGARIA
}

\author{
Magdalena Kuchcik \\ Institute of Geography and Spatial Organization \\ Polish Academy of Sciences \\ Twarda 51/55, 00-818 Warsaw, Poland \\ mkuchcik@twarda.pan.pl
}

\begin{abstract}
This paper presents contemporary climatic conditions over the years 2000-2014, as well as predictions for climate change up to 2100 in the cases of 6 meteorological stations located in Poland and 6 in Bulgaria. The present climates of Poland and Bulgaria differ markedly in terms of ranges of air temperature, numbers of non-frosty days and sums for active temperatures above 5 and $10^{\circ} \mathrm{C}$, though they prove to be similar as regards rainfall totals. In contrast, predictions suggest that climatic differences between the two countries will grow, most especially as a consequence of the forecast reduction in precipitation totals for Bulgaria.
\end{abstract}

Keywords: climate change, prognosis, air temperature, precipitation, Bulgaria, Poland.

\section{Introduction}

As evident climate change is ensuring increased interest in climate, including among ordinary people, there is a justification for comparing the current and future states of climate, and presenting climatic conditions likely to be encountered - now and in the future - by such a person travelling between Poland and Bulgaria. Such predictions of future climate are important if strategies for adaptation to climate change are to be developed, above all in agriculture. This reflects the great impact on agriculture likely to be exerted by inevitable changes in air temperature, and especially rainfall patterns. An essential strategy is thus, for example, for agriculture to adjust to fewer days with rainfall, and to precipitation totals in the $21^{\text {st }}$ century that are lower than those reported in the $20^{\text {th }}$.

While climate change is in fact a significant, emerging threat to all sectors of the economy, worldwide (WHO/WMO 2012), it is agriculture that (aside from public health) is regarded as one of the sectors most vulnerable to climate change. And, while agriculture, forestry and other land-uses of this kind are responsible for just under a quarter of anthropogenic greenhouse gases emissions (from livestock, the soil and nutrient management), these activities also obviously suffer most where precipitation totals and patterns become subject to change (Smith et al. 2014). Successive reports of the Intergovernmental Panel on Climate Change (IPCC) (Watson et al. 2001, Field et al. 2012) present many possible variant scenarios for climate change and its effects, albeit now classified to 
4 different groups of climate scenario: A1 - describes a future world of very rapid economic growth, global population that peaks in mid-century and declines thereafter, and the rapid introduction of new and more efficient technologies, A2 - describes a very heterogeneous world, B1 - describes a convergent world with the same global population, B2 - describes a world in which the emphasis is on local solutions to economic, social and environmental sustainability. In the most often studied group A1 three A1 groups were distinguished by their technological emphasis: fossil intensive (A1FI), non-fossil energy sources (A1T), or a balance across all sources (A1B) (IPCC 2007).

The last report saw use made of the so-called Representative Concentration Pathways (RCPs) to make projections on the by reference to 4 pathways of GHG emissions in $21^{\text {st }}$ century and atmospheric concentrations, air-pollutant emissions and land use. The RCPs are: a stringent mitigation scenario (RCP2.6), two intermediate scenarios (RCP4.5 and RCP6.0) and one scenario with very high GHG emissions (RCP8.5) (IPCC 2014). The RCPs are not in fact a complete package of socioeconomic, emission and climate projections, but rather internally-consistent sets of projections of the components to radiative forcing used in successive phases of climate modelling. RCP6.0 is closest to A1B.

Where a climatic comparison between Poland and Bulgaria is concerned, latitude is not the only differentiating factor, given that Poland is predominantly a lowland country in which mountains are confined to its far south. $75.1 \%$ of Polish territory lies below $200 \mathrm{~m}$ a.s. 1 ., while just $3.1 \%$ is above 500 $\mathrm{m}$ a.s.l. Furthermore, Poland is also a meeting-point for maritime and continental climatic influences. In contrast, Bulgaria is much more highly-differentiated geographically, given the presence of high Balkan Mountains across the country, with the Rila and Rhodope Mountains located in the south. This effectively splits the country into distinct northern and southern parts. Overall, lowlands account for just 31.4\% of Bulgarian territory, while highlands and mountains above $600 \mathrm{~m}$ a.s.l. are present over $27.6 \%$ (Alexandrov 1997). This all ensures that a country only about one-third the size of Poland actually experiences far greater differentiation of climate.

This paper therefore compares Poland and Bulgaria in regard to the climate characteristics of greatest importance to agriculture, with account taken of observations for the years 2000-2014, as well as predictions for climate change up to the year 2100, in the cases of 6 meteorological stations located in each of the countries.

\section{Material and methods}

The current state of the two countries' climates was analysed on the basis of the data derived from National Climatic Data Center of the NOAA, in regard to the years 2000-2014. These related to daily mean, minimum and maximum air temperatures, precipitation totals, numbers of days with precipitation and days with snow cover. In each country the selection of 6 meteorological stations was made with a view to the whole area of each and their different geographical regions being represented. In Poland the stations were: Białystok, Cracow, Poznań, Szczecin, Warsaw and Wrocław; while in Bulgaria: Plovdiv, Sandanski, Sofia, Varna, Vidin and Veliko Tarnovo (Fig. 1, Tab. 1). 


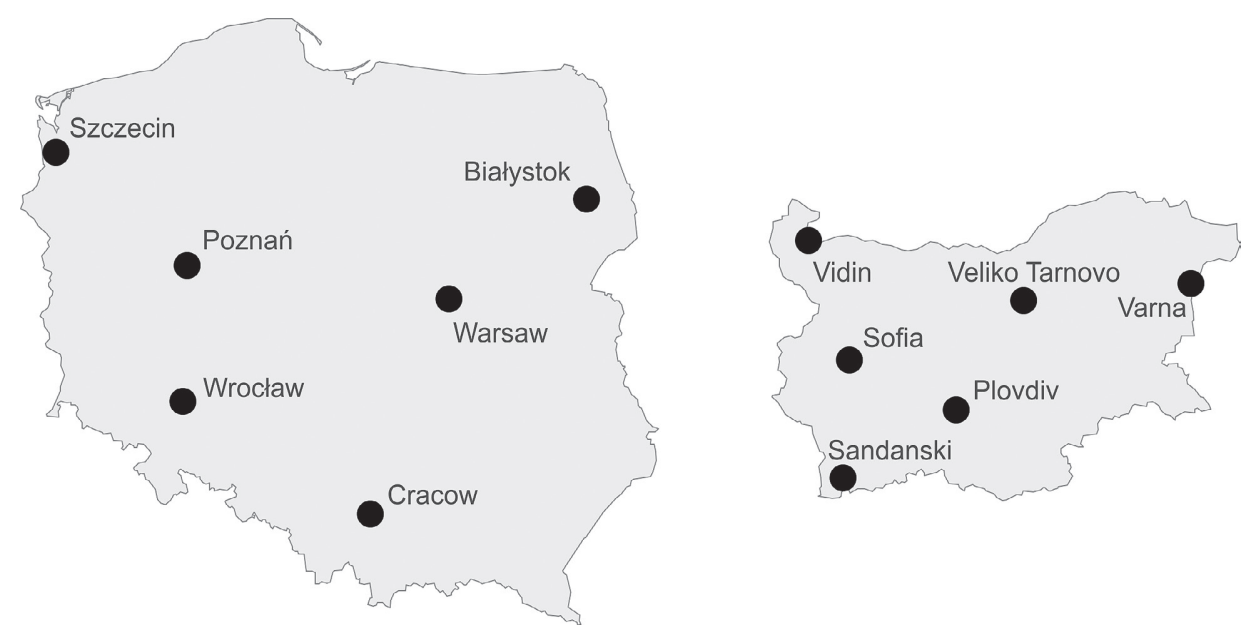

Figure 1. Meteorological stations in Poland and Bulgaria for which data were analysed (maps created by P. Milewski)

Current climatic conditions in the two countries were to be presented through calculation of:

- mean monthly air temperature;

- numbers of non-frosty days - with a minimum air temperature above $0^{\circ} \mathrm{C}$;

- numbers of days exceeding the particular thresholds of daily mean air temperature of 5 and $10^{\circ} \mathrm{C}$, as connected with the potential crop growing season in Bulgaria (Alexandrov 1997);

- sums of 'active temperatures' (Gulinova 1974, Bac \& Rojek 1999) above 5 and $10^{\circ} \mathrm{C}$ (given that cumulative totals for temperatures above given thresholds are assumed in agroclimatology to measure warmth plants need to grow, with the crossing of such thermal thresholds marking the onset of phenological phases and with the essential condition for growth regarded as the proper sum of effective temperatures with defined solar conditions, each a little different from one species to another, and with crop growth in both Poland and Bulgaria most determined by the sums of daily temperatures above $10^{\circ} \mathrm{C}$ ) mean monthly and yearly precipitation totals;

- mean numbers of days with snow cover.

The prognoses for 2040, 2060, 2080 and 2100 were made using METEONORM, the Global Meteorological Database - version 7. In METEONORM, the statistical temperature data resource accessible to the generation process was created for approximately 8000 stations using the Globalsod data prepared by the US National Climatic Data Centre (NCDC) for the 10-year period 1996-2005. The worldwide total is of 4951 stations for which all monthly data are available. Data for nearest stations are used to supply interpolated values.

Predictions concerning temperatures and precipitation totals were based on the aforementioned A1B scenario (Watson et al. 2001). The A1 family of scenarios describes a future world of very rapid economic growth, with global population peaking in mid-century and declining thereafter, and with a rapid introduction of new and more efficient technologies. Major underlying themes are convergence among regions, capacity building, and increased cultural and social interactions, with a substantial reduction in regional differences in per capita income. The A1B scenario assumes a balance between fossil and non-fossil energy sources, with $\mathrm{CO}_{2}$ emissions in decline by 2100 .

In general, days with precipitation are reproduced quite well by METEONORM. Tests show that days with precipitation are rendered precisely. The calculations are fitted to monthly means, rather 
than yearly means, but even yearly sums correspond more or less with input values. However, it is typical for calculated maximum daily sums and numbers of hours with precipitation to be on the low side. Nevertheless, the deviations and different magnitudes characterising precipitation under different climates are clearly observable and much more difficult to forecast than air-temperature characteristics.

\section{Results}

\section{Current climate}

In presenting and comparing climatic conditions in Poland and Bulgaria, use was made of the Köppen-Geiger classification, as adapted by Peel et al. (2007) (Fig. 2). The meteorological stations selected represent either cold or temperate climates, and, according to the Köppen-Geiger classification, with all the Polish stations being 'cold', with a dry season lacking and with a warm summer, even if secondary features of climate are found to differ. The Bulgarian climate is far more differentiated, with four 'cold-climate' stations (of which three are similar to their counterparts in Poland, while the fourth (Sandanski) is of the 'hot summer+dry season' type. That leaves two Bulgarian stations characterised by a temperate climate and summers that are either warm (Vidin) or hot (Varna) (Tab. 1).

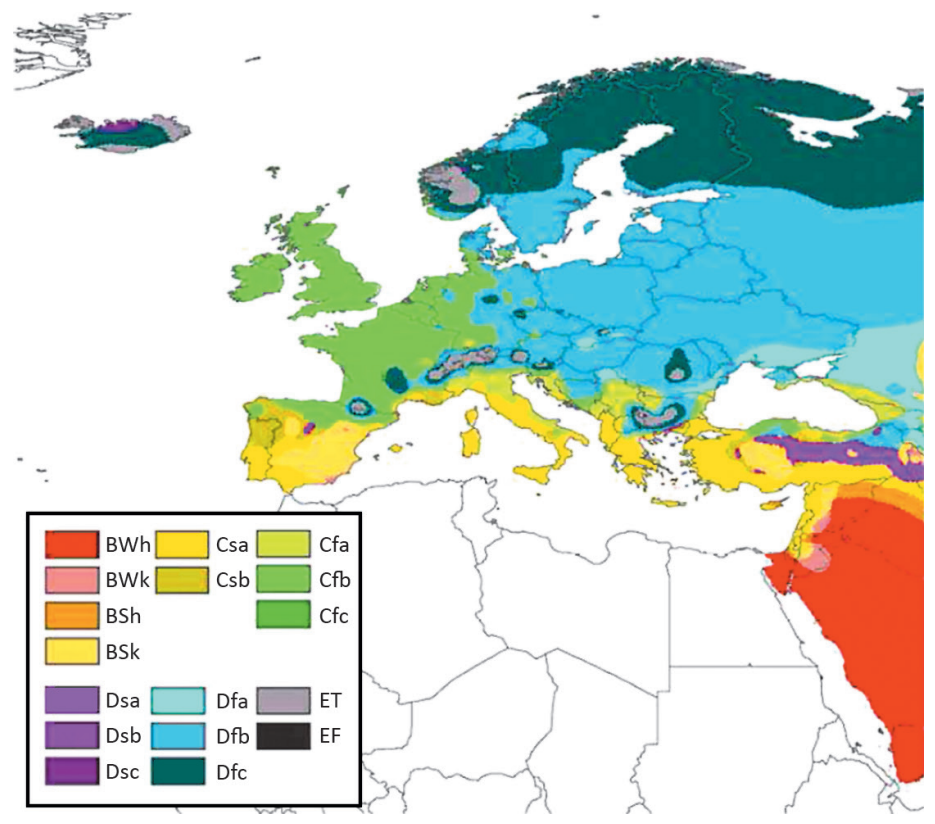

Figure 2. Köppen-Geiger climate type map for Europe: A - tropical, B - arid, C - temperate, D - cold (boreal), E - polar Source: Peel et al. 2007. 
Table 1. Climate features of the stations selected, in terms of the Köppen-Geiger climate classification

\begin{tabular}{|c|c|c|c|}
\hline Station & Symbol & General climate features & Location of station \\
\hline \multicolumn{4}{|c|}{ Poland - cold climates $\left(\mathrm{T}_{\text {hot }}>10^{\circ} \mathrm{C} \& \mathrm{~T}_{\text {cold }} \leq 0^{\circ} \mathrm{C}\right)$, without a dry season, with severe winters and humid } \\
\hline Białystok & \multirow{6}{*}{$\mathrm{Dfb}$} & \multirow{6}{*}{$\begin{array}{c}\text { warm summer } \\
\left(4 \text { or more months with } \mathrm{T}>10^{\circ} \mathrm{C}\right)\end{array}$} & North Podlasie Lowland \\
\hline Cracow & & & Northern Subcarpathia \\
\hline Poznań & & & Greater Poland Lakeland \\
\hline Szczecin & & & vicinity of Baltic Sea Coast \\
\hline Warsaw & & & Central Polish Lowland \\
\hline Wrocław & & & Silesian Lowland \\
\hline \multicolumn{4}{|c|}{ Bulgaria - cold climates $\left(\mathrm{T}_{\text {hot }}>10^{\circ} \mathrm{C} \& \mathrm{~T}_{\text {cold }} \leq 0^{\circ} \mathrm{C}\right)$} \\
\hline Veliko Tarnowo & \multirow{3}{*}{$\mathrm{Dfb}$} & \multirow{3}{*}{$\begin{array}{c}\text { warm summer } \\
\left(4 \text { or more months with } \mathrm{T}>10^{\circ} \mathrm{C}\right)\end{array}$} & $\begin{array}{l}\text { Yantra River valley, } \\
\text { north slopes of Balkan } \\
\text { Mountains }\end{array}$ \\
\hline Plovdiv & & & Thracian Lowland \\
\hline Sofia & & & Sofia Valley \\
\hline Sandanski & Dsa & $\begin{array}{l}\text { hot summer }\left(\mathrm{T}_{\text {hot }} \geq 22^{\circ} \mathrm{C}\right) \text { and dry } \\
\left(\mathrm{P}_{\text {sdry }}<40 \mathrm{~mm}\right)\end{array}$ & Foot of Pirin Mountains \\
\hline \multicolumn{4}{|c|}{ Bulgaria - temperate climates $\left(\mathrm{T}_{\text {hot }}>10^{\circ} \mathrm{C} \& \mathrm{~T}_{\text {cold }} 0-18^{\circ} \mathrm{C}\right)$, without dry season } \\
\hline Varna & Cfa & hot summer $\left(\mathrm{T}_{\text {hot }} \geq 22^{\circ} \mathrm{C}\right)$ & Black Sea Coast \\
\hline Vidin & $\mathrm{Cfb}$ & $\begin{array}{c}\text { warm summer } \\
\left(4 \text { or more months with } \mathrm{T}>10^{\circ} \mathrm{C}\right)\end{array}$ & Danubian Plain \\
\hline
\end{tabular}

$\mathrm{T}_{\text {hot }}$ - average temperature of the hottest month, $\mathrm{T}_{\text {cold }}$ - average temperature of the coldest month,

$\mathrm{P}_{\text {sdry }}$ - precipitation totals for the driest month.

Source: Peel et al. 2007.

In Poland mean annual air temperature for the period $2000-2014$ inclusive ranges from $7.6^{\circ} \mathrm{C}$ in the north-east (Białystok), $8.9^{\circ} \mathrm{C}$ in Cracow and Warsaw, $9.0^{\circ} \mathrm{C}$ in Szczecin, $9.5^{\circ} \mathrm{C}$ in Poznań up to $9.8^{\circ} \mathrm{C}$ in the south-west (Wrocław). The coldest month is January, with negative temperatures in all cities. However, mean monthly air temperatures below zero occur in the whole December-February period, in the cases of Białystok, Cracow and Warsaw. July is markedly the warmest month, though even then it is only in Warsaw that the mean monthly air temperature exceeds $20^{\circ} \mathrm{C}$ (Fig. 3).

The mean annual air temperature in Bulgaria ranges from $10.9^{\circ} \mathrm{C}$ in Sofia, through $11.7^{\circ} \mathrm{C}$ (Veliko Tarnovo), $12.0^{\circ} \mathrm{C}$ (Vidin), $12.5^{\circ} \mathrm{C}$ (Varna) and $12.8^{\circ} \mathrm{C}$ (Plovdiv), up to $14.5^{\circ} \mathrm{C}$ at Sandanski in the south-west. The coldest month is again January, albeit with minus temperatures at just three stations situated in the northern and central parts of Bulgaria (i.e. Sofia, Veliko Tarnovo and Vidin). The warmest months are in turn July and August, with average temperature reaching $26.2^{\circ} \mathrm{C}$ in Sandanski. Equally, a mean air temperature of $20^{\circ} \mathrm{C}$ is exceeded across the entire June-August period, at all of the Bulgarian stations except Sofia (Fig. 3).

Frost-free days are a very important environmental factor, given that crossing of the $0^{\circ} \mathrm{C}$ barrier denotes freezing and thawing of natural and artificial liquids, with this playing a great role in the whole natural and anthropogenic environment. Changes in frost-free seasons influence phenology, the life-cycles of insects and hence outbreaks of pests. This is important, not only for agriculture, horticulture or forestry, but also in such other sectors of the economy as building and road construction, transport, or the heating industry, especially in high-latitude regions. A change in the number 
of frosty days would demand adaptation to new crop species and new plant protection agents, as well as denoting a lengthening of the construction season (Bielec-Bąkowska \& Piotrowicz 2011).

Numbers of frost-free days at the different stations in Poland do not differ very markedly, given the figure of 234.6 for the north-east (Bialystok), as compared with around 260 days in the west, and a peak of 263.7 noted for the Poznan station (Fig. 4A). In Bulgaria, the range is greater with Sofia's rather low total of 246.9 frost-free days comparing with the 253.7 days at Veliko Tarnovo, which is situated in a valley favouring the occurrence of frosts. With their lowland locations, Vidin and Plovdiv report 273-279 days without frost, while the figure for the Black Sea coast is 287.6 days and that for Sandanski 313.8 (Fig. 4B).
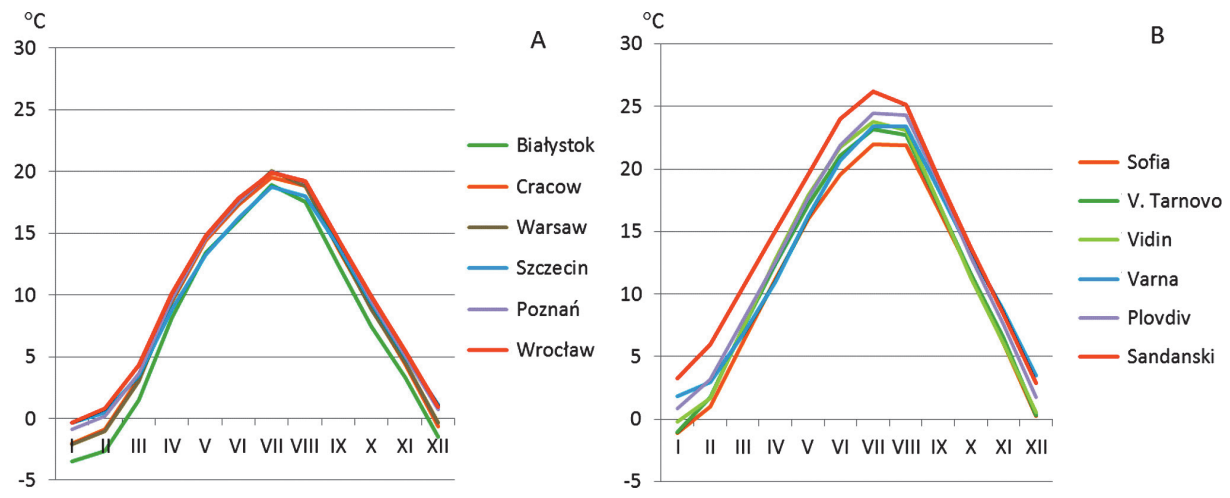

Figure 3. Mean air temperature at the selected stations in Poland (A) and Bulgaria (B), over the years 2000-2014
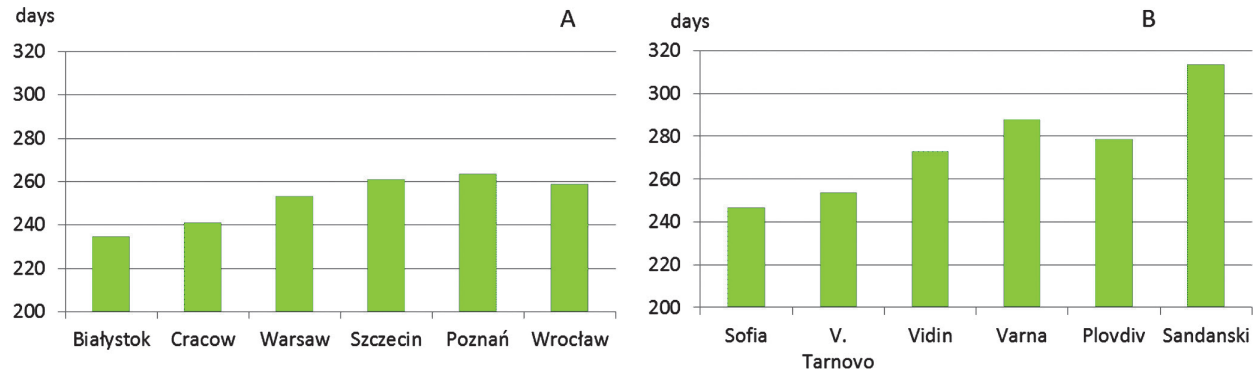

Figure 4. Mean numbers of non-frosty days reported for the stations in Poland (A) and Bulgaria (B), over the years 2000-2014

A further characteristic of climate of importance to agriculture is the number of days below or above the aforementioned $5^{\circ} \mathrm{C}$ and $10^{\circ} \mathrm{C}$ thresholds (Tab. 2). The crossing of the 0,5 and $10^{\circ} \mathrm{C}$ thresholds are regarded as important for growing plants. The proportions for these different categories of day in Poland and Bulgaria are found to differ significantly. In Poland, the numbers of days in the year with a mean daily air temperature below or equal to $5^{\circ} \mathrm{C}$ are in the range 111 in the south-west, to 144 in the north-east, or some $30-39 \%$ of the days in the year. The number of days with temperatures in the $5-10^{\circ} \mathrm{C}$ range is 61 in the south-west, as compared with 75 close to the Baltic coast (i.e. $17-20 \%$ days of a year). Finally, days with a mean temperature above $10^{\circ} \mathrm{C}$ number 160 in the north-east, i.e. the most continental part of Poland, as compared with 185 in Wrocław, which is within one of Poland's warmest regions. These are thus figures representing $44-51 \%$ of the days in the year. 
The situation for these thresholds is rather different in Bulgaria, as days with a mean daily air temperature below or equal to $5^{\circ} \mathrm{C}$ range from 62 in number in Sandanski in the south-west, up to 103 in Sofia (this is therefore some $17-28 \%$ of the days in the year). In turn, days with a temperature of between 5 and $10^{\circ} \mathrm{C}$ prove to be similarly frequent to in Poland (accounting for $15-18.5 \%$ of the days of the year). That leaves a very marked difference between the countries when it comes to days with a mean temperature above $10^{\circ} \mathrm{C}$. There are 206 such days a year in Sofia, and as many as 241 of them in Sandanski; with these figures equating to between 56 and $66 \%$ of the days in a year) (Tab. 2).

Table 2. Mean numbers of days with mean daily air temperatures above the 5 and $10^{\circ} \mathrm{C}$ thresholds at the studied stations in Poland and Bulgaria, over the years 2000-2014

\begin{tabular}{|c|c|c|c|c|c|c|}
\hline \multicolumn{7}{|c|}{ Poland } \\
\hline T range & Białystok & Cracow & Warsaw & Szczecin & Poznań & Wrocław \\
\hline$\leq 5^{\circ} \mathrm{C}$ & 144.3 & 128.0 & 126.1 & 118.1 & 116.7 & 110.8 \\
\hline $5.1-10^{\circ} \mathrm{C}$ & 61.1 & 62.1 & 64.7 & 75.3 & 69.2 & 69.1 \\
\hline$>10^{\circ} \mathrm{C}$ & 159.5 & 174.9 & 174.2 & 171.5 & 179.1 & 185.1 \\
\hline \multicolumn{7}{|c|}{ Bulgaria } \\
\hline & Sofia & Veliko Tarnovo & Vidin & Varna & Plovdiv & Sandanski \\
\hline$\leq 5^{\circ} \mathrm{C}$ & 103.1 & 97.1 & 98.3 & 78.7 & 84.5 & 61.7 \\
\hline $5.1-10^{\circ} \mathrm{C}$ & 56.1 & 54.0 & 54.5 & 67.7 & 59.1 & 62.3 \\
\hline$>10^{\circ} \mathrm{C}$ & 205.8 & 213.9 & 212.2 & 218.7 & 221.4 & 241.0 \\
\hline
\end{tabular}

The sums for daily temperatures above $5^{\circ} \mathrm{C}$ and $10^{\circ} \mathrm{C}$ determine the growth of most plants and are called active temperatures. In Poland, summed active temperatures above $5^{\circ} \mathrm{C}$ range from the 1898 reported for Białystok to almost 2337 in the case of Wrocław (Fig. 5A). In Bulgaria, even the lowest figure - for Sofia - is far higher at 2766, while the highest reported figure is of no less than 3718 , in the case of Sandanski (Fig. 5B). The sums for temperatures above $10^{\circ} \mathrm{C}$ are shown to deviate from 946 to 1231 in Poland. In these terms, the readings for Bulgaria again start above the highest total recorded for Poland, ranging between 1598 and 2348. Figure 6. makes the difference between the two countries plain.
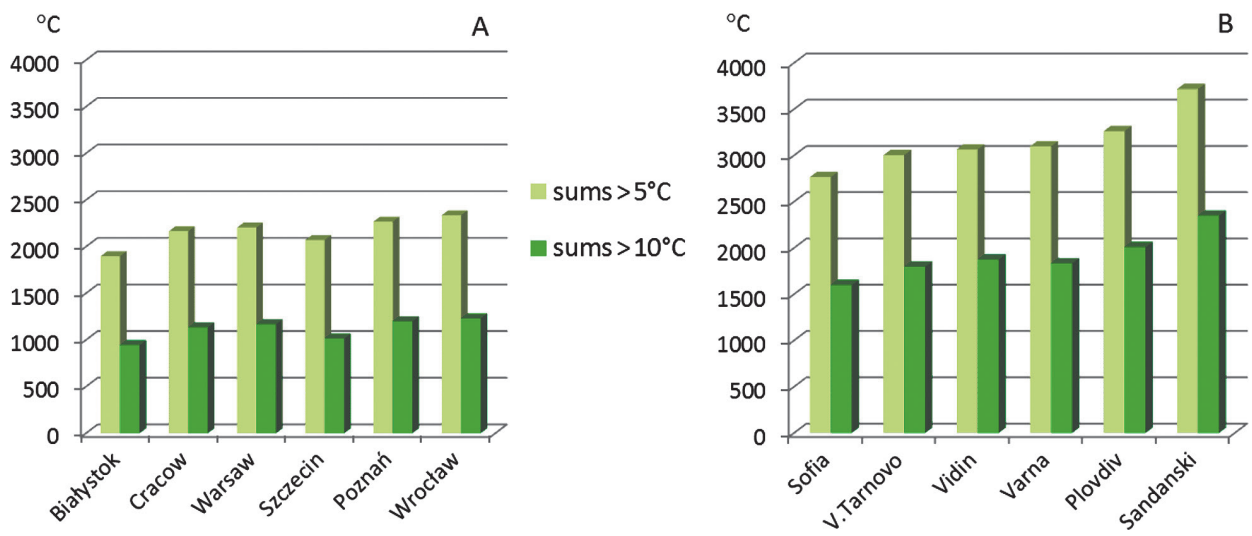

Figure 5. Active temperatures - the sums for mean daily air temperatures above $5^{\circ} \mathrm{C}$ or $10^{\circ} \mathrm{C}$, with thresholds noted for both Poland (A) and Bulgaria (B), over the years 2000-2014 

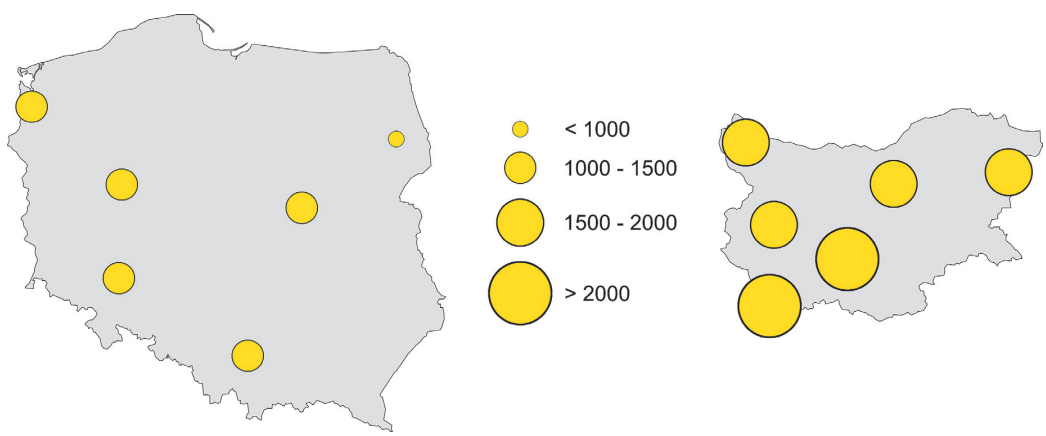

Figure 6. Active temperatures $\left({ }^{\circ} \mathrm{C}\right)$ above $10^{\circ} \mathrm{C}$ in Poland and Bulgaria over the years 2000-2014 (maps created by P. Milewski)

Precipitation in Poland and Bulgaria differs significantly in terms of the yearly course, and slightly where the totals are concerned. The Polish July is a month with distinctly highest precipitation (at over $80 \mathrm{~mm}$, with even $108 \mathrm{~mm}$ in Cracow). In other summer months the rainfall totals are lower (at about 60-70 mm). In turn, the lowest precipitation totals are those noted through the February-April period. The differences between, for example, Wrocław and Szczecin, are seen to clear, if not very large. Only Cracow stands out in this respect, with precipitation totals higher than in the rest of Poland noted from March through to July in a manner somewhat reminiscent of the annual course of rainfall noted for Bulgaria. Annual totals for precipitation in Poland, as reported at the beginning of the $21^{\text {st }}$ century ranged between $562 \mathrm{~mm}$ in the case of Poznan and $589 \mathrm{~mm} \mathrm{n}$ Warsaw, to the $681 \mathrm{~mm}$ characterising Cracow (Tab. 3).

The yearly course in Bulgaria is flatter, with small changes between successive months, even if differences between regions are much greater than those noted in Poland. Precipitation totals in fact range from the $521 \mathrm{~mm}$ noted for Varna on the Black Sea coast, to over $700 \mathrm{~mm}$ in Veliko Tarnovo in the Balkan Mountains (Fig. 7). Highest precipitation is on average noted from May to July and in August. In May, Veliko Tarnovo's rainfall reaches $90 \mathrm{~mm}$, while Sofia has $76 \mathrm{~mm}$ and Varna just $39 \mathrm{~mm}$. At the remaining Bulgarian stations, precipitation is in the $55-57 \mathrm{~mm}$ range. In contrast, the June rainfall totals for Sofia and Vidin are similar (at ca $75 \mathrm{~mm}$ ), while Sandanski reports just ca $45 \mathrm{~mm}$. Each station thus has a quite distinct precipitation pattern: Sofia with its highest rainfall at the beginning of summer and its lowest in winter; Vidin with its peak rainfall in June and July, a lower total in August and then higher levels again in autumn; and Sandanski resembling Varna though with much lower sums overall, if with the former having highest $(56 \mathrm{~mm}$ ) rainfall in May and October and the latter mainly experiencing rain in October, September and December. As Veliko Tarnovo is characterised by distinctly higher precipitation in May and September, it is clear that it is only in October that all the Bulgarian stations report similar totals for precipitation (Tab. 3). 
Table 3. Mean monthly precipitation totals (mm) recorded for Poland and Bulgaria over the years 2000-2014

\begin{tabular}{|l|c|c|c|c|c|c|c|c|c|c|c|c|c|}
\hline \multicolumn{10}{|c|}{ Poland } \\
\hline \multicolumn{1}{|c|}{ Station } & I & II & III & IV & V & VI & VII & VIII & IX & X & XI & XII & year \\
\hline Białystok & 40.8 & 33.7 & 30.6 & 32.8 & 68.9 & 64.3 & 93.8 & 84.0 & 53.8 & 40.3 & 39.3 & 35.8 & 618.1 \\
\hline Cracow & 46.3 & 30.1 & 42.6 & 43.3 & 81.9 & 86.7 & 108.0 & 66.9 & 61.5 & 37.7 & 42.5 & 33.8 & 681.4 \\
\hline Warsaw & 39.9 & 34.6 & 29.5 & 36.2 & 62.4 & 63.6 & 96.0 & 74.2 & 46.1 & 32.7 & 37.3 & 36.6 & 589.1 \\
\hline Szczecin & 40.5 & 36.2 & 37.3 & 31.7 & 50.2 & 60.1 & 82.1 & 69.6 & 54.7 & 46.5 & 42.5 & 44.5 & 595.8 \\
\hline Poznań & 42.2 & 31.8 & 38.1 & 32.7 & 58.1 & 57.0 & 85.5 & 62.5 & 42.4 & 33.7 & 36.5 & 42.0 & 562.4 \\
\hline Wrocław & 35.1 & 27.3 & 36.1 & 31.6 & 71.2 & 62.1 & 94.5 & 69.5 & 50.1 & 33.1 & 34.3 & 29.3 & 574.4 \\
\hline & & & & & & & & & & \\
\hline \multicolumn{1}{|c|}{ Station } & I & II & III & IV & V & VI & VII & VIII & IX & X & XI & XII & year \\
\hline Sofia & 39.1 & 29.1 & 41.8 & 54.9 & 76.4 & 76.1 & 63.6 & 62.3 & 63.4 & 58.9 & 30.5 & 43.8 & 640.0 \\
\hline Vidin & 43.3 & 43.0 & 38.4 & 50.9 & 55.5 & 74.6 & 72.9 & 42.1 & 59.6 & 53.0 & 43.6 & 52.3 & 629.1 \\
\hline Sandanski & 34.7 & 38.6 & 41.6 & 35.6 & 56.2 & 44.3 & 43.1 & 34.5 & 54.0 & 56.0 & 50.0 & 51.3 & 539.9 \\
\hline Plovdiv & 44.4 & 32.7 & 43.5 & 46.5 & 57.3 & 58.5 & 64.2 & 43.4 & 55.2 & 53.0 & 26.7 & 51.4 & 576.7 \\
\hline V. Tarnovo & 49.1 & 41.0 & 52.4 & 52.0 & 89.6 & 69.5 & 71.2 & 49.5 & 77.2 & 58.2 & 33.8 & 57.2 & 700.8 \\
\hline Varna & 51.2 & 33.2 & 36.5 & 29.0 & 39.2 & 46.0 & 46.1 & 33.6 & 55.2 & 59.5 & 35.8 & 55.4 & 520.8 \\
\hline
\end{tabular}
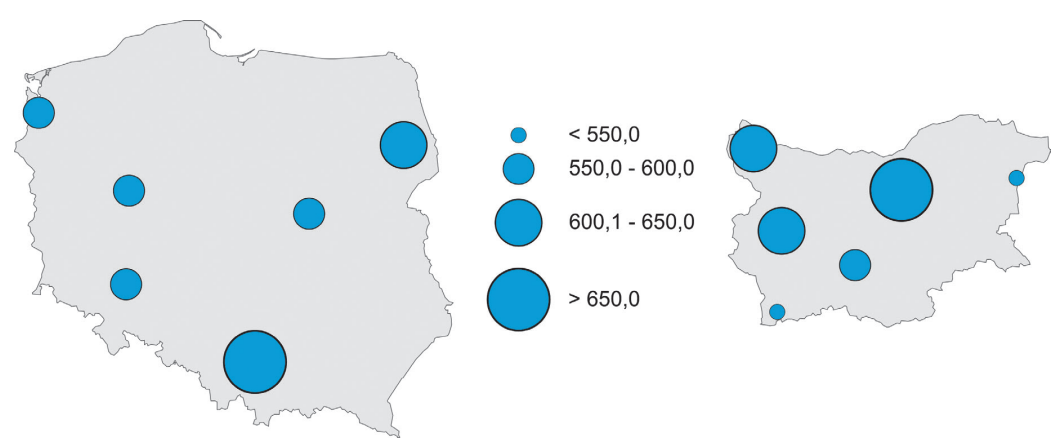

Figure 7. Mean annual precipitation totals $(\mathrm{mm})$ reported for the stations in Poland and Bulgaria over the years 2000-2014 (maps created by P. Milewski)

The last climatic characteristic analysed in the course of the work described here is the number of days with snow cover, which is found to separate Poland and Bulgaria in a quite striking way. While the maximum snow-cover period is similar in the two countries, extending from October to April in Poland (though from November to April in Poznań and Szczecin); as well as from November to March (in the south and east to February) in Bulgaria. However, while the mean number of days with snow cover annually in Poland ranges from 30 by the Baltic Sea to 76 in the most continental north-east of Poland (Fig. 8A), the figures for Bulgaria are as low as 15 in the case of Sandanski, through with 27 reported for Varna and as many as 56 for Sofia (Fig. 8B). 

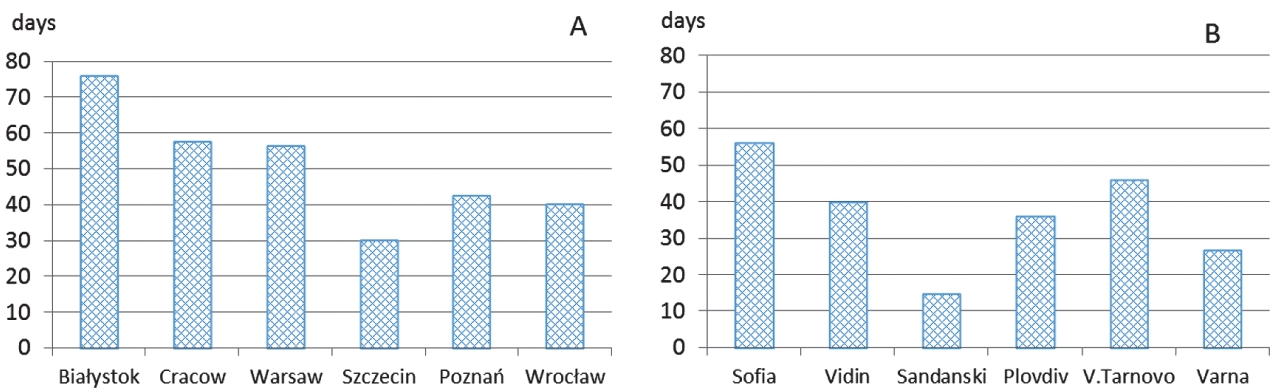

Figure 8. Mean number of days with snow cover in Poland (A) and Bulgaria (B) over the years 2000-2014

\section{Future climate}

According to the last IPCC report, the change in average surface temperature and precipitation for the years 2081-2100 as compared with 1986-2005 will be large when set against the natural internal variability (IPCC 2014). In line with different RCPs applied to Poland, the average rise in surface temperature is projected to amount to between $1-1.5^{\circ} \mathrm{C}(\mathrm{RCP} 2.6)$ and $4-5^{\circ} \mathrm{C}(\mathrm{RCP} 8.5)$, while average precipitation levels will either remain the same or increase by up to $10 \%$. Corresponding figures for Bulgaria are of between $1-1.5^{\circ} \mathrm{C}$ and $5-7^{\circ} \mathrm{C}$, albeit with a $10-30 \%$ decline in average precipitation.

The calculations made for this paper were based on the A1B scenario. According to these, the coldest city in Poland will see an increase in the annual mean air temperature of $2.9^{\circ} \mathrm{C}$ to $10.5^{\circ} \mathrm{C}$ by 2100 , as compared with a rise of 2.1 to $11.9^{\circ} \mathrm{C}$ in the case of the country's warmest city. Hence, the anticipated rise in mean air temperature could be of $38 \%$ in the north-east and of just $22 \%$ in the south-west (Fig. 9A). In Bulgaria, in turn, the mean air temperature characterising Sofia is predicted to grow from $11.0^{\circ} \mathrm{C}$ today to $13.9^{\circ} \mathrm{C}$, while that for the warmest station will rise from $14.5^{\circ} \mathrm{C}$ now to $17.8^{\circ} \mathrm{C}$ at the end of the $21^{\text {st }}$ century. In percentage terms, this in fact denotes a smaller rise in mean annual temperature than in Poland: by $23 \%$ in Sandanski and maximally by $30 \%$ in Veliko Tarnovo (Fig. 9B).
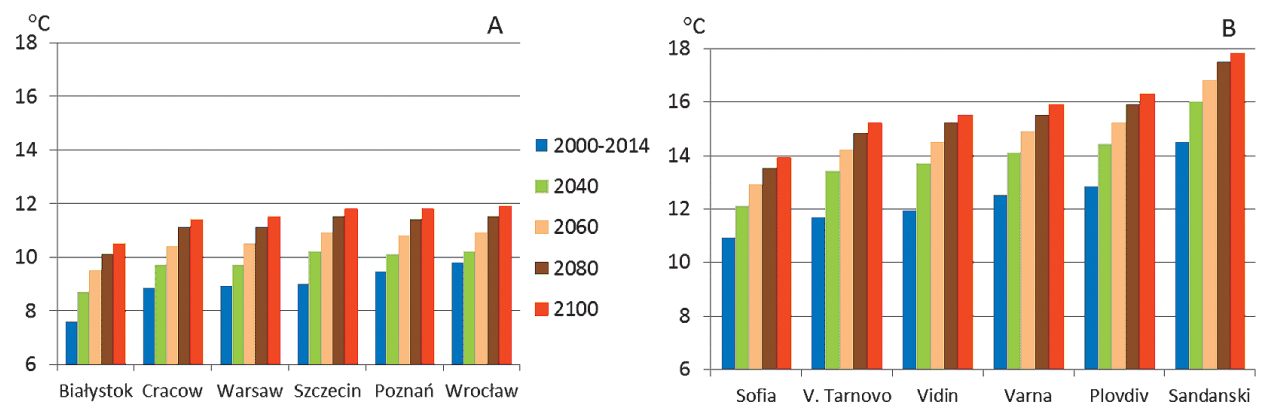

Figure 9. Mean air temperature measured over the years 2000-2014 and forecast up to the year 2100 for the selected stations in Poland (A) and Bulgaria (B) 

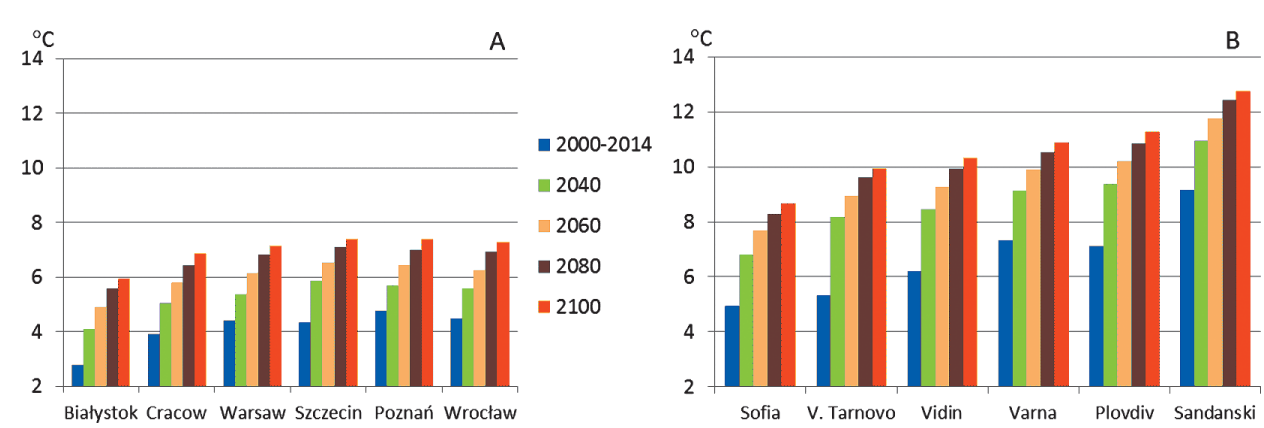

Figure 10. Minimum air temperature over the years 2000-2014 and forecast up to 2100 for the selected stations in Poland (A) and Bulgaria (B)
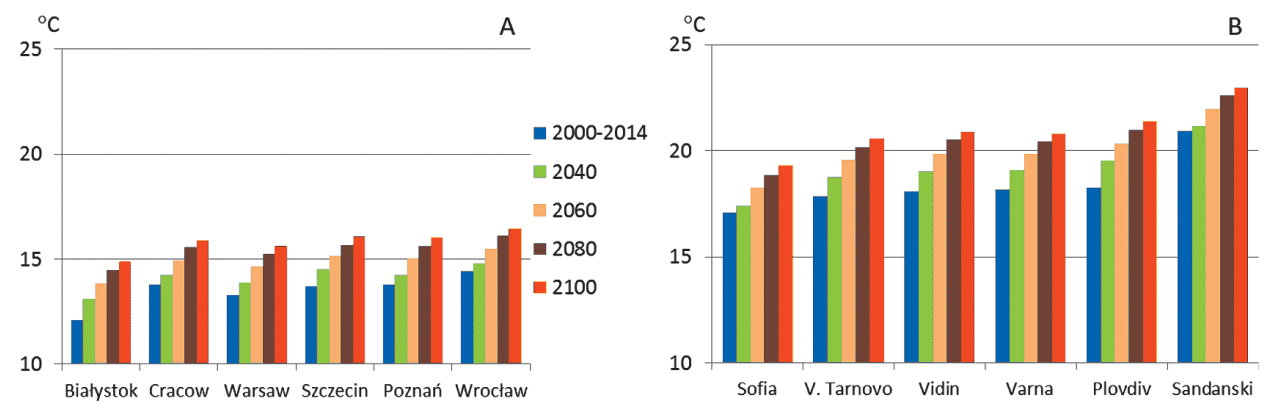

Figure 11. Maximum air temperature over the years 2000-2014 and forecast up to 2100 for the selected stations in Poland (A) and Bulgaria (B)

The minimum air temperature is predicted to rise from $2.8^{\circ} \mathrm{C}$ to $5.9^{\circ} \mathrm{C}$ in Białystok and from $4.8^{\circ} \mathrm{C}$ to $7.4^{\circ} \mathrm{C}$ in Poznan (Fig. 10A). In Bulgaria, the minimum air temperature will end up much higher, with values predicted to grow from $4.9^{\circ} \mathrm{C}$ to $8.7^{\circ} \mathrm{C}$ in the case of Sofia, and from $9.2^{\circ} \mathrm{C}$ to $12.8^{\circ} \mathrm{C}$ in the warmest locality of Sandanski (Fig. 10B).

In turn, values for maximum air temperature are forecast to rise from the $12.1^{\circ} \mathrm{C}$ reported for the 2000-2014 period to $14.9^{\circ} \mathrm{C}$ by the end of the $21^{\text {st }}$ century in Białystok and from $14.4^{\circ} \mathrm{C}$ to $16.4^{\circ} \mathrm{C}$ in the case of the relatively warm Wrocław (Fig. 11A). Maximum air temperatures in Bulgaria could in turn rise from $17.1^{\circ} \mathrm{C}$ to $19.3^{\circ} \mathrm{C}$ in Sofia and from $21.0^{\circ} \mathrm{C}$ recently to $23.0^{\circ} \mathrm{C}$ in the case of Sandanski (Fig. 11B).

It is the minimum air temperature that is forecast to rise markedly during the $21^{\text {st }}$ century, rather than the maximum. Especially spectacular is the rise predicted for Białystok, which is in Poland's coldest region. The rise here could even be of $113 \%$ compared with now (i.e. more than double). The percentage rises anticipated for the remaining Polish cities range from $55 \%$ in the case of the relatively warm Poznań to $74 \%$ in the quite-cold Cracow (Fig. 12). In turn, the percentage rises forecast for minimum air temperature in Bulgaria up to the end of $21^{\text {st }}$ century as compared with now could range from the $39 \%$ predicted in the case of Sandanski to the $86 \%$ anticipated for Veliko Tarnovo (Fig. 12). This means that it is the coldest areas in each of the countries studied that are expected to see the most marked increases in temperature, while the rises of this kind will be smallest in what are already the warmest parts. 

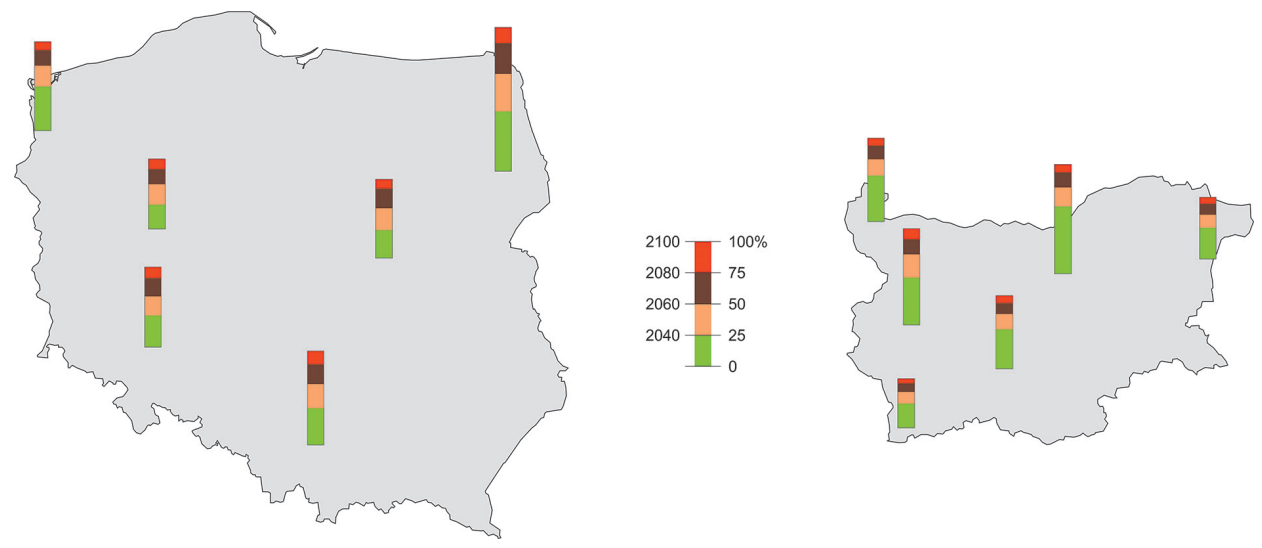

Figure 12. The percentage rises in minimum air temperature up to 2100 predicted for selected stations in Poland and Bulgaria (maps created by P. Milewski)

The rises predicted for maximum air temperature are significantly more limited, if with the same pattern again duplicated, in that the most marked rises are foreseen for the coldest parts of each country. In Poland, these values reach $14 \%$ in the case of Wrocław, 23\% in Białystok. Consistently, the rises forecast for Bulgaria are smaller, at between 10\% in the case of Sandanski and $15 \%$ in those of Veliko Tarnovo and Vidin (Fig. 13).
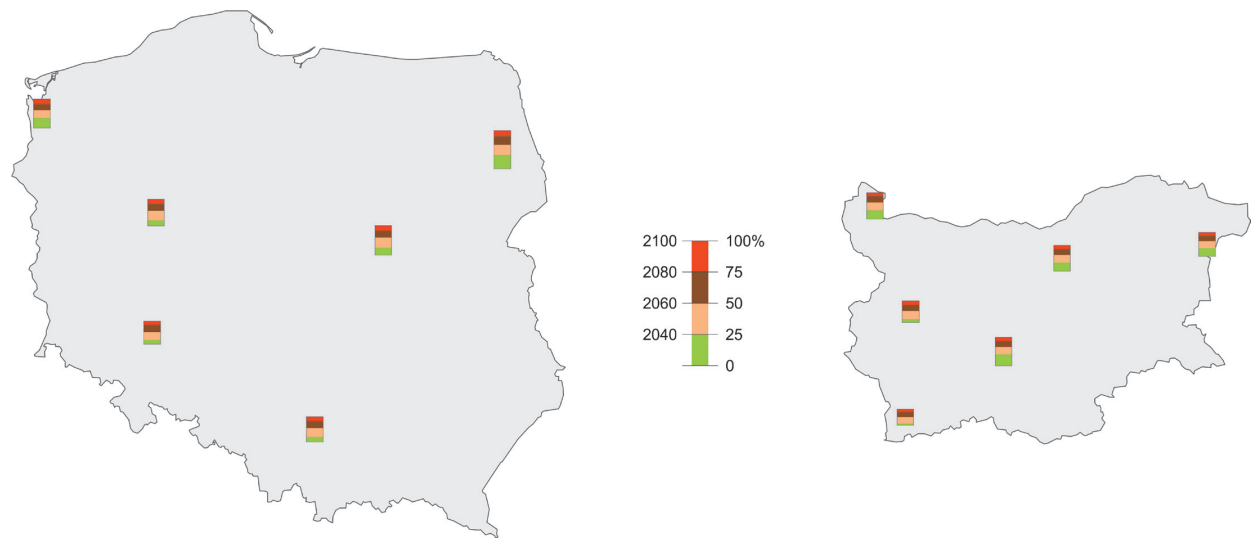

Figure 13. The percentage rises in maximum air temperature up to 2100 predicted for selected stations in Poland and Bulgaria (maps created by P. Milewski)

Precipitation is a meteorological element of a non-continuous nature that proves very variable both temporally and spatially and hence very hard to predict. The forecasting of precipitation is thus burdened by greater uncertainties than that involving air temperature, and different models give rise to quite dissimilar outputs (Hawkins \& Sutton 2011, Shield \& Dai 2015). While reference to a longer time series of input data would most likely help reduce this source of uncertainty, and improve the overall quality of output data, the METEONORM series of input data is indeed short (covering the 1996-2005 period). This part of the paper must thus be seen as the most dubious. 

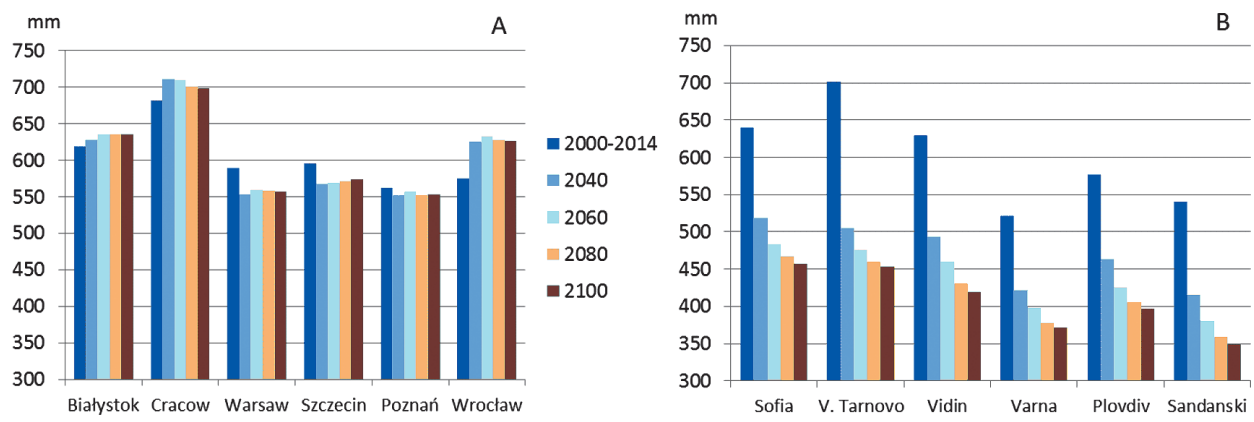

Figure 14. Mean annual precipitation totals as measured over the years 2000-2014 and predicted up to 2100 in the cases of the selected stations in Poland (A) and Bulgaria (B)
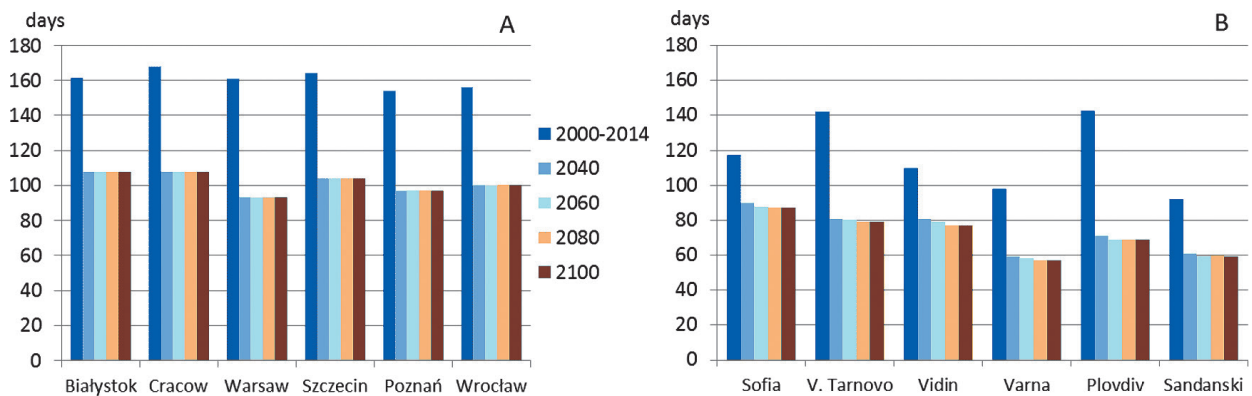

Figure 15. Mean number of days annually on which precipitation was observed in the years 2000-2014 or is predicted for the years to 2100, at the selected stations in Poland (A) and Bulgaria (B)

In fact, the precipitation totals forecast for Poland are similar to those being noted at present. By 2100 , forecast totals in central and north may be slightly (2-6\%) below those recorded today, while those in the south and north-east are forecast to be $2-10 \%$ higher. The most marked change is predicted for Wrocław (Fig. 14A). In the case of Bulgaria, the prognoses are much less favourable. All areas are expected to experience major declines in precipitation totals, with Veliko Tarnovo and Sandanski receiving up to $35 \%$ less precipitation than they do at present. However, the situation in absolute terms could be especially difficult in the case of Sandanski, given that its annual precipitation could be as low as $350 \mathrm{~mm}$ by the end of the century. Such values today being associated with desertification (Fig. 14B).

While forecast precipitation totals for Poland and Bulgaria are seen to differ greatly, the picture as regards the forecast numbers of days with precipitation resemble one another. Both countries are expected to experience a significant fall in the numbers of days with precipitation: from 154-168 days noted now to 93-108 days by the second part of the $21^{\text {st }}$ century, in the case of Poland (with falls in the range between the $33 \%$ predicted for Białystok and the $42 \%$ anticipated for Warsaw); and from the 92-143 days observed at present in Bulgaria, to just 57-87 days (and this representing declines between $25 \%$ in Sofia and a massive $52 \%$ in the case of Plovdiv) (Fig. 15). Overall, this means Poland receiving a similar amount of precipitation, if on fewer days (and hence more intensive precipitation events). In contrast, Bulgaria will experience declines in both the numbers of days on which precipitation falls and the total amounts received. This therefore denotes a clear threat to agriculture and the economy in Bulgaria. 


\section{Conclusions}

The rise in annual mean air temperature forecast to the end of the present century is more limited in Bulgaria's case than that of Poland, even if the values characterising the former country are obviously higher. Poland's forecast rise in minimum air temperature is expected to be 3.5-4.9 times as high as that characterising maximum air temperature, with that characterising Bulgaria being 3.3-5.9 times as great. The most marked rises in air temperature are predicted for the coldest areas in each country, while the smallest increases should occur in parts that are already identified as the warmest.

'On paper' comparisons for numbers of frosty days and for precipitation totals reveal much better conditions for agriculture in Bulgaria (especially its central and northern parts) than in Poland. However, the facts fail to support the theoretical contention, given that Poland was the EU's $6^{\text {th }}$ most important producer of food, and indeed a major exporter, as of $2014.30 \%$ of the food produced in Poland is in fact exported, mainly to Germany. Despite its much better conditions, Bulgaria produces only one-third as much grain as Poland, and only one-seventh the weight of tomatoes. In turn, where apples, cattle and pork are concerned, Poland respectively produces 58, 60 and 32 times as much (Eurostat 2015). These figures show what a poor state Bulgarian agriculture is in, making it clear which importing food has proved a necessity for the country.

While precipitation totals in the two countries are similar at present, with some Bulgarian stations even receiving more precipitation than their Polish counterparts, the forecast is for the two to diversify markedly as the $21^{\text {st }}$ century goes on. This reflects the fact that, while Poland's precipitation totals are forecast to decline only slightly, Bulgaria is expected to experience a huge drop in both precipitation totals and the numbers of days on which precipitation is recorded. Desertification could worsen an already poor situation and force Bulgarian agriculture to use costly technologies to grow crops.

Concluding, it can be noted that changing climate will necessitate changes in many economic sectors, but most especially in the agriculture practised in both Poland and Bulgaria. Nevertheless, the predictions are more alarming where Bulgaria is concerned. From the economic point of view, some compensatory solutions might be found through development and improvement of the level and range of Bulgaria's offer where tourism is concerned, especially given the unstable political situation in the Mediterranean region.

\section{References}

Alexandrov V.A, 1997. Vulnerability of agronomic systems in Bulgaria. Climatic Change, vol. 36, pp. 135-149.

Bac S., Rojek M., 1999. Meteorologia i klimatologia winżynierii środowiska. Wrocław: Wydawnictwo Akademii Rolniczej, 314 pp.

Bielec-Bąkowska Z., Piotrowicz K., 2001. Wieloletnia zmienność okresu bezprzymrozkowego w Polsce w latach 1951-2006. Prace i Studia Geograficzne, no. 47, pp. 77-86.

Eurostat, 2015. Agriculture. http://ec.europa.eu/eurostat/statistics-explained/index.php/Agriculture [20 September 2015].

Field C.B., Barros V., Stocker T.F., Qin D., Dokken D.J., Ebi K.L., Mastrandrea M.D., Mach K.J., Plattner G.K., Allen S.K., Tignor M., Midgley P.M. (ed.), 2012. Managing the risks of extreme events and disasters to advance climate change adaptation. A special report of working groups 
I and II of the Intergovernmental Panel on Climate Change. Cambridge: Cambridge University Press, United Kingdom and New York, NY, USA, 582 pp.

Gulinova N., 1974. Methods in agricultural climatology. St. Petersburg: Gidrometeoizdat, 260 pp. Hawkins E., Sutton R., 2011, The potential to narrow uncertainty in projections of regional precipitation change. Climate Dynamics, vol. 37, no. 1, pp. 407-418.

IPCC, 2007. Summary for Policymakers [in:] Climate Change 2007: The Physical Science Basis. Contribution of Working Group I to the Fourth Assessment Report of the Intergovernmental Panel on Climate Change. S. Solomon, D. Qin, M. Manning, Z. Chen, M. Marquis, K.B. Averyt, M. Tignor and H.L. Miller (eds.), Cambridge University Press, Cambridge, United Kingdom and New York, NY, USA.

IPCC, 2014. Climate Change 2014: Mitigation of climate change, summary for policymakers. 32 pp. http://www.ipcc.ch/pdf/assessment-report/ar5/syr/AR5_SYR_FINAL_SPM.pdf [1 October 2015].

Peel M.C., Finlayson B.L., Mcmahon T.A., 2007. Updated world map of the Köppen-Geiger climate classification. Hydrology and Earth System Sciences, vol. 11, no. 5, pp. 1633-1644.

Shield S., Dai Z., 2015. Comparison of uncertainty of two precipitation prediction models. Atmospheric and Oceanic Physics, DOI arXiv:1508.03662.

Smith P., Bustamante M., Ahammad H., Clark H., Dong H., Elsiddig E.A., Haberl H., Harper R., House J., Jafari M., Masera O., Mbow C., Ravindranath N.H., Rice C.W., Robledo Abad C., Romanovskaya A., Sperling F., Tubiello F., 2014. Agriculture, forestry and other land use (AFOLU). [in:] O. Edenhofer, R. Pichs-Madruga, Y. Sokona, E. Farahani, S. Kadner, K. Seyboth, A. Adler, I. Baum, S. Brunner, P. Eickemeier, B. Kriemann, J. Savolainen, S. Schlömer, C. von Stechow, T. Zwickel and J.C. Minx (eds.), Climate Change 2014: Mitigation of Climate Change. Contribution of Working Group III to the Fifth Assessment Report of the Intergovernmental Panel on Climate Change, Cambridge: Cambridge University Press, United Kingdom and New York, NY, USA, pp. 811-922.

Watson R.T., Core Writing Team (eds.), 2001. Climate Change 2001: Synthesis Report. A contribution of working groups I, II, and III to the Third Assessment Report of the Intergovernmental Panel on Climate Change. Cambridge: Cambridge University Press, United Kingdom and New York, NY, USA, 398 pp.

WHO/WMO, 2012. Atlas of health and climate. WMO-No 1098, Geneva: WHO Press, 68 pp. 
